\title{
Dental fluorosis associated with chronic ingestion of dentifrices - what health professionals should know
}

\author{
Fluorose dentária associada à ingestão crônica de dentifrícios - o que profissionais de saúde devem saber
Fluorosis dental asociada a la ingestión crónica de crema de dientes con flúor - lo que debe saber el professional de la salud

Rosa Virginia Dutra de Oliveira. Universidade Estadual Paulista Júlio de Mesquita Filho (UNESP). Araraquara, SP, Brasil. drarosadutra@hotmail.com Fernanda Lourenção Brighenti. Universidade Estadual Paulista Júlio de Mesquita Filho (UNESP). Araraquara, SP, Brasil. fbrighenti@foar.unesp.br (Autora correspondente)

\section{Abstract}

This paper reports on two cases of dental fluorosis caused by inadvertent ingestion of fluoridated dentifrice. An eight-year-old child showed whitish spots and loss of dental enamel in first permanent molars and whitish spots without structure loss in permanent incisors and primary second molars, whereas a fourteen-year-old teenager showed whitish spots in all permanent teeth. In both cases, homologue teeth were affected similarly and mothers did not report on the use of fluoride supplements during pregnancy or children's infancy. The water fluoridation of the city where they live is considered optimal. Both patients reported eating dentifrice frequently during tooth brushing and in other occasions. Mothers also stated that they did not receive instructions about oral hygiene or about the fact that chronic ingestion of dentifrice could contribute to the development of dental fluorosis. It is believed that the cooperative work between dentists and other health professionals is a way to prevent the occurrence of this condition.

\section{Resumo}

Este artigo relata dois casos de fluorose dentária causada pela inadvertida ingestão de dentifrício fluoretado. Uma criança de oito anos apresentou manchas brancas e perda de esmalte dentário nos primeiros molares permanentes, bem como manchas brancas sem perda de estrutura nos incisivos e segundos molares decíduos, enquanto um adolescente de quatorze anos apresentou manchas brancas em todos os dentes permanentes. Em ambos os casos, dentes homólogos foram afetados similarmente e as mães não relataram uso de suplementos fluoretados durante a gestação ou infância. A fluoretação da água da cidade onde eles vivem é ótima. Ambos relataram ingerir dentifrício frequentemente durante a escovação e em outras ocasiões. Mães também afirmaram não ter recebido instruções sobre higiene oral ou que a ingestão crônica de dentifrício poderia contribuir para desenvolver fluorose dentária.Acredita-se que o trabalho cooperativo entre dentistas e outros profissionais de saúde é uma forma de prevenir a ocorrência desta condição.

\section{Resumen}

Este trabajo reporta dos casos de fluorosis dental causada por inadvertida ingestión de dentífricos con flúor. Un paciente de ocho años presentaba manchas blancas y perdida de esmalte dental en los primeros molares permanente y manchas blancas sin pérdida de estructura en los incisivos e segundos molares deciduos, mientras que un adolescente de catorce años presentaba manchas blancas en todos los dientes permanentes. En ambos casos, dientes homólogos fueron afectados y las madres no relataron uso de suplementos fluoretados durante la gestación o infancia. El agua fluoretada donde ellos vivían era adecuada. En los dos casos hubo ingestión de flúor durante el cepillado así como en otras ocasiones. Las madres también informaron no haber recibido instrucciones profesionales en higiene oral y que la ingestión crónica de dentífricos con flúor podría contribuir para desarrollar fluorosis dental. De esta forma, el trabajo conjunto entre odontólogos y otros profesionales de la salud es una forma de prevenir la incidencia de esta condición.

\section{Keywords:}

Fluorosis, Dental

Dentifrices

Child

Palavras-chave

Fluorose Dentária Dentifrícios

Criança

Palabras clave:

Fluorosis Dental Dentífricos Niño 


\section{Introduction}

Dental fluorosis is a systemic side effect of chronic excessive fluoride intake. ${ }^{1}$ The inadvertent ingestion of fluoridated dentifrice may be an important contributor to the occurrence of this disease. Its prevalence and severity depends on the tooth enamel mineralization phase, when excessive exposure to fluoride occurs, on the amount of fluoride ingested and absorbed, on the duration of fluoride exposure and on individual characteristics. ${ }^{2-4}$

Some variables influence dentifrice intake in childhood, such as the inadequate control of swallowing, ${ }^{5}$ dentifrice flavor, ${ }^{6-8}$ amount of dentifrice used ${ }^{9,10}$ and lack of parental supervision during toothbrushing ${ }^{7,8}$. Hence, discussing with other health professionals the main causes and preventive measures that should be taken is important and will provide a transdisciplinary approach to children's oral health.

Since in the Family Health Strategy parents have a frequent contact with nurses and physicians during routine follow-up visits, even before dentists, it is important that these and other professionals involved in Primary Health Care are also informed about oral health care. To the best of our knowledge, very little is published about dental fluorosis for general health professionals. Therefore, the purpose of this paper is to describe two cases of patients seen at a Pediatric Dentistry outpatient clinic that showed dental fluorosis.

\section{Description of the cases}

Differential diagnosis of dental fluorosis was done following the sequence described by Cutress and Suckling $(1990)^{11}$. This sequence considers the presence of enamel defects, opacities, symmetry (opacities affecting two or more teeth), the presence of an endemic condition (checking for atypical exposure to fluorides) and medical history.

\section{Case Report 1: T.C.R., female, 8 years old.}

The child came to the Pediatric Dentistry outpatient clinic for regular follow up. The child presented a good oral health and good oral hygiene. The mother revealed that all permanent teeth of the child erupted with whitish spots. Medical history showed that the child had no systemic diseases and good dietary habits. The child's family history reveled that no other family members were affected, ruling out the involvement of genetic diseases on teeth discoloration. The mother did not report the use of fluoride supplements during pregnancy or during the child's infancy. Water fluoridation of the city where they live (Araraquara-SP, Brazil) is considered optimal. The possibility of dental fluorosis was raised when the mother draw attention to the fact that the child used to spend the whole afternoon eating a tutti-frutti-flavored dentifrice $\left(\right.$ Tandy $^{\mathrm{TM}}$ 1,100 ppm F) when she was under her grandmother's care. Permanent incisors showed white opacities without enamel structure loss (Figure 1), there were enamel defects characterized by symmetric white opacities in other permanent teeth (Figure 2) and there was structure loss in upper and lower first permanent molars (Figure 3). These clinical features, added to the high levels of fluoride exposure during childhood, indicated the diagnosis of dental fluorosis.

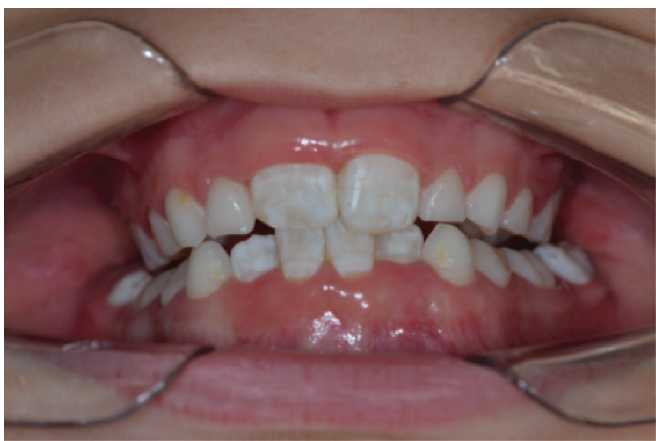

Figure 1. White opacities without enamel structure loss in permanent incisors.

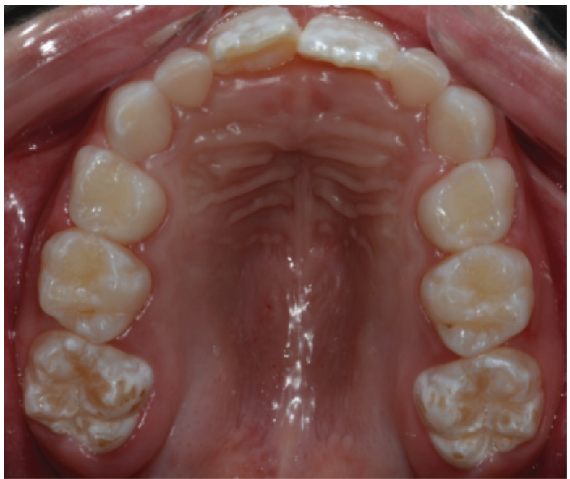

Figure 2. Symmetric white opacities in permanent teeth (view of the upper arch).

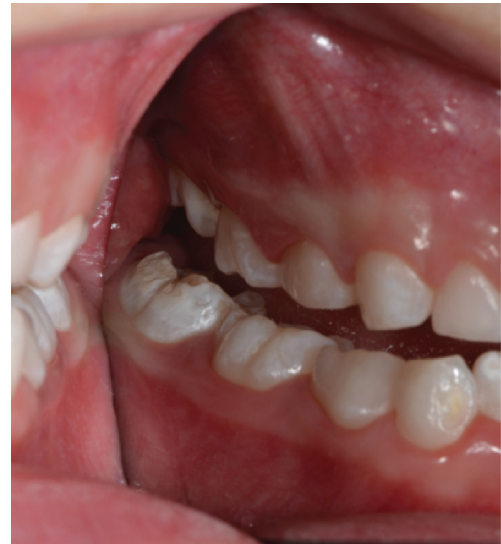

Figure 3. Dental enamel loss in first permanent molars (left side view). 
Since there were no esthetical complains, it was decided - together with the child and her mother - that no treatment would be done for now. The defects in first permanent molars were small and the mother preferred a follow-up at short intervals before placing any restorative material in these areas.

\section{Case Report 2: K.S.S., male, 14 years old}

K.S.S. came to the Pediatric Dentistry outpatient clinic to change some discolored restorations, but did not complain about his stained teeth. The child had a good oral hygiene. During medical history evaluation, it was reported that the teenager had no systemic diseases and showed good dietary habits. No other family members were affected, discarding the possibility of genetic diseases. The mother did not report the use of fluoride supplements during pregnancy or during the child's infancy. Water supplies of the city where they live also are within the tolerable limits of fluoride. The teenager also reported frequent ingestion of a tutti-frutti-flavored dentifrice (Tandy ${ }^{\mathrm{TM}} 1,100 \mathrm{ppm} \mathrm{F}$ ) during tooth brushing and in other occasions throughout his infancy. During the clinical examination, white opacities were found in all permanent teeth (Figure 4), affecting similarly homologue teeth (Figure 5), except for the upper central incisors and lower central incisors which were restored due to dental trauma. Enamel structure loss was not observed. Considering the data collected, the child was diagnosed with dental fluorosis.

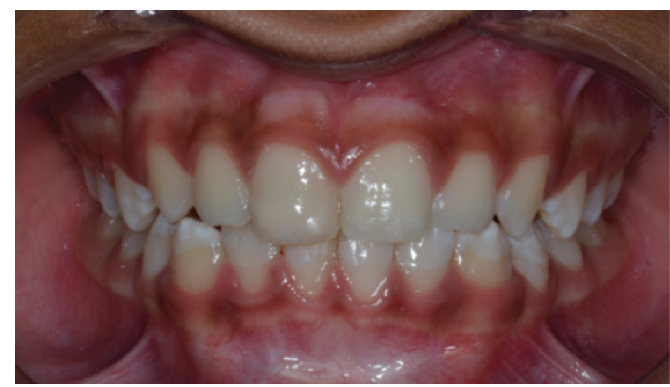

Figure 4. White opacities in all permanent teeth.

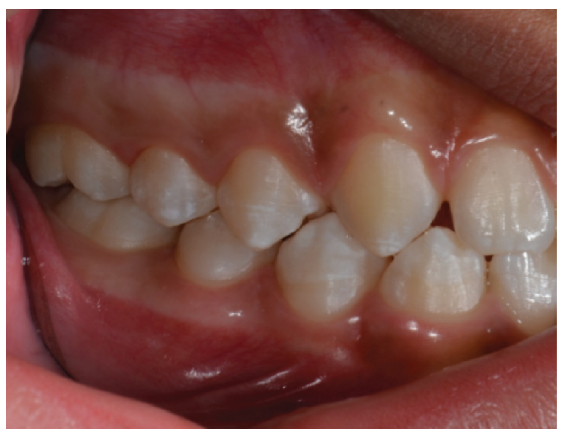

Figure 5. White opacities affecting similarly homologue teeth (left side view).

It is important to emphasize that, in both cases, mothers also stated that they did not receive instructions about oral hygiene or about the fact that the chronic intake of dentifrice could contribute to the development of dental fluorosis.

\section{Discussion}

Dental fluorosis is a systemic side effect of chronic and excessive fluoride intake during the enamel-forming period. ${ }^{1}$ People are exposed to different sources of fluoride such as foods, beverages, supplements, water, dentifrices and other therapeutic products. In these cases, the inadvertent and excessive ingestion of fluoridated toothpastes was identified as the main source of fluoride.

The extent to which the disease affects each tooth and the number of teeth affected are directly related to the duration of fluoride ingestion during childhood. In both clinical cases, more than one tooth was affected, which indicates that excessive fluoride exposure started early and lasted for a long time. This correlates well to the time parents reported their children started ingesting dentifrices in other periods besides tooth brushing. For permanent dentition, the age of major susceptibility to the development of dental fluorosis is from birth to approximately 8 years old and is correlated to the enamel formation period. ${ }^{12}$ In Case 1, the presence of enamel structure loss (Figure 3) indicates that fluoride exposure started early in this child. Molars start their formation earlier than incisors. ${ }^{12}$ As some permanent teeth were not yet erupted, the extension of dental fluorosis in this child is not totally known.

Important variables can be involved in dentifrice intake during childhood. The unconscious ingestion of dentifrice during tooth brushing is very common until 6 years old, because children have not yet developed an adequate control over the swallowing reflex. Nonetheless, this problem is naturally solved as children grow. ${ }^{5}$ The pleasant flavor of children's 
dentifrice may also stimulate the non-expectoration as well as promote the intentional ingestion of this product. ${ }^{7}$ Although some studies found that dentifrice flavor did not influence the percentage of fluoride intake and that the amount used was more important than the type of dentifrice, ${ }^{9,10}$ both patients reported that the pleasant flavor encouraged the ingestion not only during tooth brushing, but also in other occasions, such as in between meals. In these occasions, the stomach is empty and fluoride absorption is increased. ${ }^{13}$ Thus, the amount of dentifrice and its flavor were determinant factors for fluoride ingestion in the two cases reported in this article. These observations emphasize the importance of keeping dentifrices away from children, ${ }^{14}$ the need for supervising tooth brushing ${ }^{7,8}$ and the importance of early instruction of parents regarding this problem.

In this context, the role of professionals involved in the Family Health Strategy is determinant. Most parents do not receive enough information about the risks of excessive fluoride ingestion and dental fluorosis. In both cases, mothers reported that no instructions were given about tooth brushing, about the use of dentifrices or about the risk of dental fluorosis during teeth development. Hence, it is important that professionals who provide primary health care who have the first contact with children and their parents - such as nurses and physicians - are involved and informed about oral hygiene care to advise their patients.

The main advice that the parents should be given in order to avoid excessive ingestion of dentifrice are: place a small amount of toothpaste on the bristles (approximately $0.3 \mathrm{~g}$ or roughly a pea-sized amount), ${ }^{8}$ choose dentifrices whose abrasives are based on calcium carbonate and calcium phosphate in order to reduce fluoride absorption, ${ }^{15}$ supervise children during tooth brushing ${ }^{8}$ and keep dentifrices away from them. ${ }^{14}$ It is known that toothpastes with low fluoride concentrations (less than 1,000 ppm of fluoride) do not provide effective preventive effect against dental caries. However, a recent randomized clinical trial proved the efficacy of a novel acidic low fluoride dentifrice is similar to the conventional ones in a high caries risk population. ${ }^{16}$ Thus, the recommendation of this toothpaste with modified formulation should be considered as a substitute of the conventional ones, as long as the efficacy is maintained.

The disclosure of these information is very important for professionals of Primary Health Care, since studies have shown that the knowledge of health professionals in general about dental fluorosis is inadequate. ${ }^{17,18}$ Discussing how to prevent the disease and publishing articles about this issue in journals targeted to the Family Health Strategy may assist other health professionals in this educational process, making them able to advise families during routine follow-up visits.

\section{References}

1. Hong L, Levy SM, Broffitt B, Warren JJ, Kanellis MJ, Wefel JS, et al. Timing of fluoride intake in relation to development of fluorosis on maxillary central incisors. Community Dent Oral Epidemiol. 2006;34:299-309. http://dx.doi.org/10.1111/j.1600-0528.2006.00281.x

2. Rojas-Sanchez F, Kelly SA, Drake KM, Eckert GJ, Stookey GK, Dunipace AJ. Fluoride intake from foods, beverages and dentifrice by young children in communities with negligibly and optimally fluoridated water: a pilot study. Community Dent Oral Epidemiol. 1999;27:288-97. http://dx.doi.org/10.1111/j.1600-0528.1999.tb02023.x

3. Almeida BS, Silva Cardoso VE, Buzalaf MA. Fluoride ingestion from toothpaste and diet in 1- to 3-year-old Brazilian children. Community Dent Oral Epidemiol. 2007;35:53-63. http://dx.doi.org/10.1111/j.1600-0528.2007.00328.x

4. Ellwood RP, Cury JA. How much toothpaste should a child under the age of 6 years use? Eur Arch Paediatr Dent. 2009;10:168-74. http://dx.doi.org/10.1007/BF03262679 PMid:19772847

5. Naccache H, Simard PL, Trahan L, Brodeur JM, Demers M, Lachapelle D, et al. Factors affecting the ingestion of fluoride dentifrice by children. J Public Health Dent. 1992;52(4):222-6. http://dx.doi.org/10.1111/j.1752-7325.1992.tb02277.x

6. Kobayashi CAN, Belini MR, Italiani FM, Pauleto ARC, Araújo JJ, Tessarolli V, et al. Factors influencing fluoride ingestion from dentifrice by children. Community Dent Oral Epidemiol. 2011;39:426-32. http://dx.doi.org/10.1111/j.1600-0528.2011.00615.x

7. Oliveira MJL, Paiva SM, Martins LHPM, Pordeus IA, Lima YBO, Cury JA. Influence of rinsing and expectoration after toothbrushing on fluoride dose and ingested amount by use of conventional and children's fluoride dentifrices. Bras Dent J. 2006;17(2):100-5. http://dx.doi.org/10.1590/S0103-64402006000200003

8. Oliveira MJ, Paiva SM, Martins LH, Ramos-Jorge ML, Lima YB, Cury JA. Fluoride intake by children at risk forthe development of dental fluorosis:comparison of regular dentifrices andflavoured dentifrices for children. Caries Res. 2007;41:460-6. http://dx.doi.org/10.1159/000107933

9. Moraes SM, Pessan JP, Ramires I, Buzalaf MAR. Fluoride intake from regular and low fluoride dentifrices by 2-3-year-old children: influence of the dentifrice flavor. Braz Oral Res. 2007;21(3):234-40. http://dx.doi.org/10.1590/S1806-83242007000300008

10. Martins CC, Oliveira MJ, Pordeus IA, Cury JÁ, Paiva SM. Association between socioeconomic factors and the choice of dentifrice and fluoride intake by children. Int J Environ Res Public Health. 2011,8,4284-99. http://dx.doi.org/10.3390/ijerph8114284 
11. Cutress TW, Suckling GW. Differential diagnosis of dental fluorosis. J Dent Res. 1990;69:714-20.

12. Pendrys DG. Analytical studies of enamel fluorosis: methodological considerations. Epidemiol Rev. 1999;21(2):233-46. Available from: http://epirev.oxfordjournals.org/content/21/2/233.full.pdf+html

13. Cury JA, Del Fiol FS, Tenuta LM, Rosalen PL. Low fluoride dentifrice and gastrointestinal fluoride absorption alter meals. J Dent Res. 2005;84:1133-7. http://dx.doi.org/10.1177/154405910508401208

14. Miziara AP, Philippi ST, Levy FM, Buzalaf MA. Fluoride ingestion from food items and dentifrice in 2-6-year-old Brazilian children living in a fluoridated area using a semiquantitative food frequency questionnaire. Community Dent Oral Epidemiol. 2009;37:305-15. http://dx.doi.org/10.1111/j.1600-0528.2009.00477.x

15. Puppin Rontani RM, Correa Kassawara AB, Delgado Rodrigues CR. Influence of socioeconomic level and dentifrice brand on the oral hygiene habits and fluoride dentifrice ingestion. J Clin Pediatr Dent. 2002;26:319-25.

16. Vilhena FV, Olympio KP, Lauris JR, Delbem AC, Buzalaf MA. Low-fluoride acidic dentifrice: a randomized clinical trial in a fluoridated area. Caries Res. 2010;44:478-84. http://dx.doi.org/10.1159/000320364

17. Vallée JG, Kandelman D. Knowledge, attitudes and practices of physicians west of Montreal Island regarding fluoride and the prevention of dental fluorosis. Can J Public Health. 1993;84(2):94-8. Available from: http://www.ncbi.nlm.nih.gov/pubmed/8334616

18. Balaban R, Aguiar CM, da Silva Araújo AC, Dias Filho EB. Knowledge of paediatricians regarding child oral health. Int J Pediatr Dent. 2012 Jul;22(4):286-91. http://dx.doi.org/10.1111/j.1365-263X.2011.01196.x 